\title{
Dietary effects upon biological performance and lambda- cyhalothrin susceptibility in the multicolored Asian lady beetle, Harmonia axyridis
}

\author{
Agna Rita dos Santos Rodrigues • \\ Aline Freitas Spíndola • \\ José Eudes de Morais Oliveira • Jorge Braz Torres
}

Received: 31 July 2012 / Accepted: 30 January 2013 / Published online: 15 February 2013

(C) Springer Science+Business Media Dordrecht 2013

\begin{abstract}
Considered a generalist species among the coccinellids, the multicolored Asian lady beetle Harmonia axyridis (Pallas) (Coleoptera: Coccinellidae) feeds upon small arthropods and non-prey plant products, a practice which might enhance its ability to colonize various ecosystems but carries the potential to expose it to prey quality variation and insecticide use. Thus, we examined the effect of four different diets on the development, reproduction, and response to the insecticide lambda-cyhalothrin in this species. Three groups of larvae received laboratory-reared diets: (i) eggs of Anagasta kuehniella (Zeller) (Ak); (ii) eggs of Sitotroga cerealella (Olivier) (Sc); and (iii) eggs of $A$. kuehniella + S. cerealella at the proportion 1:1; and one
\end{abstract}

A. R. dos Santos Rodrigues · A. F. Spíndola

J. B. Torres $(\square)$

Departamento de Agronomia - Entomologia, Universidade

Federal Rural de Pernambuco,

Dois Irmãos,

52171-900 Recife, PE, Brazil

e-mail: jtorres@depa.ufrpe.br

A. R. dos Santos Rodrigues

e-mail: agnarodrigues@yahoo.com.br

A. F. Spíndola

e-mail: aline.spin@gmail.com

J. E. de Morais Oliveira

Embrapa Semiárido,

Zona Rural,

56302-970 Petrolina, PE, Brazil

e-mail: jose.eudes@cpatsa.embrapa.br group received wild-caught cotton aphids, Aphis gossypii Glover (Ag). Notwithstanding the generalist feeding behavior of $H$. axyridis, development and reproduction results were superior with diets of $\mathrm{Ag}$ or Ak compared with the diet combining 1:1 Ak $+\mathrm{Sc}$ or the diet of Sc eggs only. Furthermore, the Sc diet did not result in satisfactory development and reproduction. Despite this significant variation in biological responses, insecticide susceptibility studies using adults that had been reared on these diets showed no statistically significant differences in susceptibility to the lambda-cyhalothrin.

Keywords Anagasta kuehniella $\cdot$ Aphis gossypii . Harlequin ladybird · Pyrethroid · Sitrotroga cerealella

\section{Introduction}

The multicolored Asian lady beetle, Harmonia axyridis (Pallas) (Coleoptera: Coccinellidae), is a cosmopolitan coccinellid found in various ecosystems (Koch 2003; Lucas et al. 2007). One of the most abundant lady beetle species in agricultural ecosystems such as corn, soybean, and cotton, it has been reported preying on many species of insect pests (Musser et al. 2004; Rutledge et al. 2004; Torres \& Ruberson 2005). Considered to be a valuable control agent due to its voracity and reproductive capacity (Berkvens et al. 2008; Brown et al. 2008), H. axyridis has been intentionally and/or accidentally introduced into North America, Europe, Africa, and South America (details 
in Koch et al. 2006). For example, in 2002 H. axyridis was found occurring naturally in Brazil (Almeida \& Silva 2002), likely moving from Argentina where it had been introduced as a biological control agent (Saini 2004). More recently, it has been found in various locations in the south, west and southeast regions of Brazil (Torres et al. 2009).

Such cosmopolitan habits carry a potential cost, however. Spread throughout various crop ecosystems, members of the species often would confront unfamiliar or uncommon diet items (Evans 2003) and encounter various insecticide sprays, including those used to control pest species not attacked by the predator. In agricultural ecosystems, lady beetles might be subjected to the effects of prey availability and quality (Honěk 1991) and also to insecticide sprays (Ruberson et al. 2007; Tillman \& Mulrooney 2000; Torres \& Ruberson 2005). These random events, both alone and in combination, might be expected to affect many aspects of their biology, including development times, adult reproductive output, and survival (Hodek \& Honěk 1996).

Knowledge of such potential effects has important practical implications. For one, conservation of natural enemy populations is a cornerstone of integrated pest management across a wide range of agroecosystems (Kogan 1998; Naranjo 2001; Torres et al. 2009) and it is widely known that when these populations are disrupted, such as occurs with improper use of broadspectrum insecticides (Eveleens et al. 1973; Torres et al. 2010), secondary pest outbreaks and the resurgence of key pests often result. Insecticides that target mature larvae of Lepidoptera and Coleoptera, the most common groups of row crop pests, are known to have a negative impact upon their natural enemies, including lady beetles (Ruberson \& Tillman 1999). In this context, attention has been drawn to the variable response that some lady beetle species show after treatment or contact with lambda-cyhalothrin residue (Ruberson et al. 2007; Tillman \& Mulrooney 2000; Torres \& Ruberson 2005). This pyrethroid insecticide is considered to have a large impact on natural enemies (Tillman \& Mulrooney 2000), often causing acute toxicity (Ruberson et al. 1998).

Other practical outcomes of such knowledge include greater success with laboratory-based rearing colonies for further releases using the best prey item (Schanderl et al. 1988) and improved ability to infer the capacity of the species to survive and thrive in different habitats (Evans 2003; Kamo et al. 2010). For example, studies of the biology of lady beetles using eggs of different species of Lepidoptera [Anagasta (=Ephestia) kuehniella (Zeller), Phthorimaea operculella (Zeller) and Sitotroga cerealella (Olivier)] have shown that they might replace aphids as food to the lady beetles (Abdel-Salam \& Abdel-Baky 2001; Gautam 1990; Schanderl et al. 1988).

Based on the broad diet used by $H$. axyridis, this study investigated two hypotheses: (i) the generalist feeding behavior of $H$. axyridis might furnish this species with the ability to exhibit similar development and reproduction on different types of diets; and (ii), the diet upon which $H$. axyridis are reared might influence adult beetle response to a stressor agent such as exposure to lambda-cyhalothrin. Thus, the study was set up to evaluate the development and reproduction of $H$. axyridis fed four types of diet - either one of two species of lepidopteran eggs (A. kuehniella and S. cerealella), their combination, or the cotton aphid, Aphis gossypii Glover - and to examine subsequent responses of adult beetles to the insecticide lambdacyhalothrin.

\section{Materials and methods}

The biological traits and susceptibility of $H$. axyridis to the pyrethroid lambda-cyhalothrin were studied in individuals reared on three different laboratory diets - eggs of A. kuehniella (Ak), eggs of S. cerealella (Sc), and a 50:50 mixture of Ak + Sc eggs - and one field diet - the cotton aphid, A. gossypii (Ag). The study began with neonate larvae of $H$. axyridis at F3 generation in the laboratory; the field diet began with A. gossypii (Ag) at the F8 generation. To allow comparison of $H$. axyridis susceptibility to lambdacyhalothrin for beetles reared upon A. gossypii at F8 generation, adults of $H$. axyridis were also obtained by rearing the larvae with $A$. kuehniella eggs. All experiments were conducted in the laboratory at $25 \pm 1^{\circ} \mathrm{C}$ and $12 \mathrm{~h}: 12 \mathrm{~h}$ (L:D) photoperiod. The study was carried out in the Biological Control and Insect Ecology Laboratory at the Universidade Federal Rural de Pernambuco, Recife, Pernambuco.

Multicolored Asian lady beetle rearing The H. axyridis population studied was established in the laboratory from individuals collected in a spontaneous 
growth field of radish (Raphanus sativus L.) located in Jaboticabal County, São Paulo $\left(21^{\circ} 14^{\prime} 0.9^{\prime \prime} \mathrm{S}\right.$ and $48^{\circ}$ $\left.19^{\prime} 0.9^{\prime \prime} \mathrm{W}\right)$. Adults were housed in plastic containers of 1,000-ml volume. On each container lid there was an opening $5-\mathrm{cm}$ in diameter covered with $2-\mathrm{mm}$ mesh nylon. Wrinkled paper towels were placed inside the rearing containers as shelters and substrates for oviposition. Egg batches were collected and placed in 500$\mathrm{ml}$ plastic containers; eclosed larvae were reared in these until they molted into second instar. Right after this molt, two larvae from each container were transferred to $80-\mathrm{ml}$ plastic vials to be reared to emerging adults. These rearing containers included eggs of $A$. kuehniella as food and wrinkled paper towels as substrate.

Diets studied The four diets were eggs of $S$. cereallela, eggs of A. kuehniella, a 50:50 combination of these, and cotton aphids, A. gossypii. The moth eggs were obtained from laboratory colonies of the respective moths, and aphids were obtained from infested cotton plants grown in an open-sided greenhouse. Eggs of $S$. cerealella were acquired from Embrapa Semiárido, Petrolina, PE. Eggs of A. kuehniella were produced in the laboratory by rearing moth larvae to adulthood on a diet of whole wheat flour (45\%), yellow corn flour (45\%), and yeast $(10 \%)$ after the method of Torres et al. (1995).

Biological traits of $H$. axyridis reared on different diets The experiment was set up using newly hatched larvae $(<12 \mathrm{~h}$ old $)$. The larvae were reared individually in 80 -ml plastic containers with a paper towel substrate and their respective diet. In the case of cotton aphids. they were offered on pieces of cotton leaves. All diets were offered ad libitum according to the following treatments: (i) eggs of A. kuehniella (Ak, $n=57$ larvae); (ii) eggs of S. cerealella (Sc, $n=62$ larvae); (iii) 50:50 combination of $\mathrm{Ak}+\mathrm{Sc}$ eggs $(n=62$ larvae); and (iv) nymphs and adults of $A$. gossypii (Ag, $n=38$ larvae). The development period, survival, and adult body weight within $24 \mathrm{~h}$ of reaching adulthood were determined.

Sexes of emerging adults were determined by the method of McCornack et al. (2007) and individuals were isolated for 3 days, then paired and maintained following the same regimens that had been applied to the larvae. The number of females evaluated, which varied according to the immature stage survival per treatment and the need for same age adults at the day of pairing, was as follows: (i) $\mathrm{Ak}(n=15$ females); (ii) Sc $(n=11$ females); (iii) Ak + Sc ( $n=15$ females); and (iv) $\mathrm{Ag}$ ( $n=16$ females). The adults were maintained under controlled conditions of $25 \pm 1^{\circ} \mathrm{C}$ and $12 \mathrm{~h}: 12 \mathrm{~h}$ photoperiod.

Adult beetle performance was evaluated based on the age for first oviposition, egg viability, reproductive period as the period of maximum reproductive effort (considered as the time required to produce 12 egg batches), and survival within this period. The egg batches were collected and stored in $80-\mathrm{ml}$ plastic containers to monitor egg hatching. Because the maximum reproductive effort of lady beetles takes place during the first weeks of life (Dixon \& Agarwala 2002), there was no need to monitor the entire adult life span when evaluating dietary effects on reproduction of these bugs (Michaud 2005; Michaud \& Grant 2005).

Susceptibility to lambda-cyhalothrin when reared on different diets To evaluate the susceptibility of the lady beetle to the insecticide lambda-cyhalothrin when reared on different diets, the mortality dose-response was estimated for $H$. axyridis reared en masse on an $\mathrm{Ak}, \mathrm{Ak}+$ $\mathrm{Sc}$, or Ag diet. The treatment Sc was not included in this experiment because of low survival for larvae fed only this diet (see below). Given a diet of solely Sc eggs, even a culture established with 300 newly hatched larvae did not yield enough adult beetles for the two replications required for the dose-response bioassay. The source of lambda-cyhalothrin was the commercial product Karate Zeon $50 \mathrm{CS}$ (lambda-cialotrina $5 \% \mathrm{~m} / \mathrm{v}-50 \mathrm{~g} l^{-1}$, Syngenta S.A., São Paulo) purchased on the local specialized market. Pilot tests were conducted with a concentration $20 \mathrm{~g}$ a.i. $\mathrm{ha}^{-1}\left(0.1 \mathrm{~g}\right.$ a.i. $\left.l^{-1}\right)$, based on the recommended concentration of the commercial product to control cotton bollworm, Heliothis virescens (Fabr.) (Lepidoptera: Noctuidae) in cotton because this is the highest concentration recommended to spray cotton. The doses (g a.i. $l^{-1}$ of water) used in the bioassay were previously determined and prepared by diluting the commercial product in distilled water. A total of 5-6 doses were tested that at least produced a response between 0 and $100 \%$ mortality.

Insects from each diet (control and treated) were subjected to two replications. A total of 173 and 245 adults of $H$. axyridis were tested from the $\mathrm{Ak}$ and $\mathrm{Ak}+$ $\mathrm{Sc}$ diets at the F3 generation, respectively. At the F8 
generation, 237 and 217 adults were tested from the $\mathrm{Ak}$ and $\mathrm{Ag}$ diets, respectively. The insect contamination consisted of applying $0.5 \mu \mathrm{l}$ of the dilution on the ventral part of the insect abdomen using a Hamilton ${ }^{\mathrm{TM}}$ syringe of $25 \mu \mathrm{l}$ volume. For the control group only water was applied. After the treatment, the insects were placed in petri dishes $(12 \mathrm{~cm}$ diameter, $1.5 \mathrm{~cm}$ tall) lined with filter paper and given a paste of honey and yeast (50\%:50\%) as food. Mortality was assessed $24 \mathrm{~h}$ after adult treatment. The criterion for mortality was an individual's inability to turn upright and begin to walk after being placed on its dorsum.

Data analysis For comparison among treatments and to allow for individual variability, larval survival was rated by a group of five replications. Larval survival, development time, the weights of newly emerged adults, and three adult reproductive parameters age for first oviposition, reproductive period (period to produce 12 egg batches), and egg viability — were each submitted to a normality test (Kolmogorov-D: Normal test, Proc Univariate of SAS) and variance homogeneity test (Bartlett's test), and were transformed when needed to meet the assumptions of analysis of variance (SAS Institute 2001). Significantly different means were separated using a Tukey's highly significant difference (HSD) test. Adult body weight data were submitted to the Student's $t$-test (SAS Institute 2001) to compare gender results for each diet. The proportion of adult females surviving within the period required to produce 12 egg batches from the day of pairing was compared among treatments and between pairs of treatments by the Long-Rank test through Kaplan-Meyer method using the Proc LIFTEST of SAS (SAS Institute 2001).

Mortality data were submitted to Probit Analysis (Finney 1971) using the Polo PC (LeOra Software 1987) aiming for an estimation of lethal dose $\left(\operatorname{LD}_{50}\right)$ for each population. The resistance ratios were calculated between beetles fed $\mathrm{Ak}$ and $\mathrm{Ak}+\mathrm{Sc}$ at the F3 generation, and between beetles fed $\mathrm{Ak}$ and $\mathrm{Ag}$ at the F8 generation.

\section{Results}

Biological traits of $H$. axyridis reared on different diets The type of diet significantly affected larval development time $\left(\mathrm{F}_{\mathrm{df}=3,28}=74.14, P<0.0001\right)$, pupal stage duration $\left(\mathrm{F}_{3,28}=20.69, P<0.0001\right)$, and the length of the period from neonate to adult emergence $\left(\mathrm{F}_{3,28}=95.22, P<0.0001\right)$, which ranged from 10.4 to 14.9 days, 3.9 to 4.8 days, and 14.3 to 19.7 days, respectively (Fig. 1a). H. axyridis required less time to complete their larval development when being fed on Ak eggs or Ag, as well as less time in the pupa stage when the larvae fed on Ag. Further, the whole period from newly hatched larvae to adult emergence was shorter for individuals that fed on $\mathrm{Ak}$ or $\mathrm{Ag}$ (Fig. 1a).

The survival of the larval stage varied significantly with diet $\left(\mathrm{F}_{3,28}=9.81, P<0.0001\right)$, exhibiting mean values from $47.9 \%$ to $91.7 \%$ (Fig. 1 b). The greater values for survival were obtained with larvae fed on Ak or Ag. The survival of pupae was $100 \%$ across all diets used. Thus, viability over the whole development from neonate larvae to emerging adults was similar to that found for the larval stage.

Adult body weights of $H$. axyridis varied from 19.9 to $30.1 \mathrm{mg}$ (Fig. 2a) and showed statistically significant differences as a function of the diet consumed during the larval stage $\left(\mathrm{F}_{3,28}=34.32, P<0.0001\right)$. When compared to adults that emerged from all other diets, those that emerged from larvae fed Ak eggs were larger; this finding held true both for males $\left(\mathrm{F}_{3}, 25=27.42\right.$, $P<0.0001)$ and for females $\left(\mathrm{F}_{3,24}=10.46, P<0.0001\right)$. Body weights of males and females ranged within expected values for the species (Fig. 2b). Further, average body weights for the same gender were similar across all diets used $\left(\mathrm{Ag}, \mathrm{t}_{10}=1.22, P=0.2518 ; \mathrm{Ak}\right.$, $\mathrm{t}_{13}=1.29, P=0.2193, \mathrm{Ak}+\mathrm{Sc}, \mathrm{t}_{13}=1.64, P=0.1260$; and Sc, $\mathrm{t}_{13}=0.60, P=0.5600$ ) (Fig. $2 \mathrm{~b}$ ).

Ten pairs of adults - three from larvae fed on Ag, three from larvae fed on $\mathrm{Ak}$, two from a diet of $\mathrm{Ak}+\mathrm{Sc}$ and two from an Sc diet - were disregarded in the analysis because of a lack of oviposition. One pair of adults from larvae fed on $\mathrm{Ag}$ and all pairs from larvae given Sc were discarded from the reproductive period analysis because they did not produce 12 egg batches during their whole adult lifetime. Likewise, the egg viability analysis did not include the data from the Sc diet because all egg batches produced by females reared on this diet were nonviable. Thus, based on the adult pairs generating confident data, adults of $H$. axyridis exhibited statistically significant differences in three reproductive parameters according to the diet used to rear them: first age for oviposition $\left(\mathrm{F}_{3,43}=31.7, P<0.0001\right)$, number of eggs produced $\left(\mathrm{F}_{3,43}=25.6, P<0.0001\right)$, and 


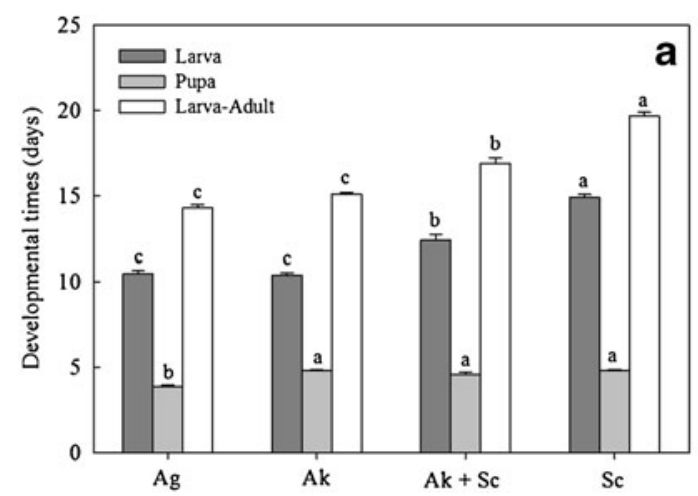

Fig. 1 Mean $( \pm \mathrm{SE})$ number of days required for larva, pupa, and larva-adult development (a), and larval survival (b) of Harmonia axyridis fed Aphis gossypii (Ag), eggs of Anagasta kuehniella (Ak), eggs of Anagasta kuehniella +

reproductive period $\left(\mathrm{F}_{2,34}=9.9, P=0.0004\right)$. Their egg viability, however, was statistically similar across the diets $\mathrm{Ak}, \mathrm{Ak}+\mathrm{Sc}$, and $\mathrm{Ag}(P=0.2940)$, varying from $57.9 \%$ to $70.5 \%$ (Table 1 ).

As measured by the period of maximum reproductive effort (time to produce at least 12 egg batches), adult female survival differed significantly among the diets (Wilcoxon's test, $\chi^{2}=15.73, P=0.0013, \mathrm{df}=3$ ) (Fig. 3). Female survival was lower across all pairwise comparisons between Sc eggs and the other diets: A. gossypii $\left(\chi^{2}=4.21, P=0.0402\right)$, Ak eggs $\left(\chi^{2}=6.63, P=0.0100\right)$, and $\mathrm{Ak}+\mathrm{Sc}$ eggs $\left(\chi^{2}=6.63, P=0.0100\right)$. However, ignoring the Sc diet, all three remaining diets promoted similar female survival over the reproductive period $\left(\chi^{2}=2.00, P=0.3679, \mathrm{df}=2\right)$.

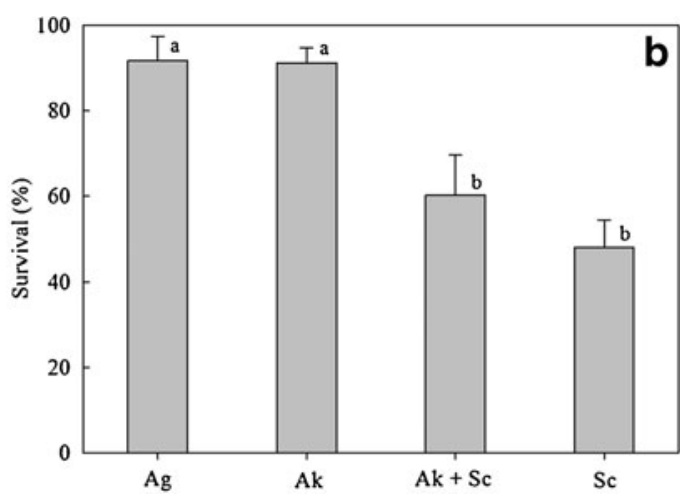

Sitotroga cerealella $(\mathrm{Ak}+\mathrm{Sc})$, and eggs of Sitotroga cerealella (Sc). In each section, columns under different letters indicate statistical significance between diets at 0.05 significance levels (Tukey's test)

Susceptibility to lambda-cyhalothrin after being reared on different diets Mortality dose-response estimations were fitted to the Probit model as indicated by the chi-square goodness-of-fit test $(P>0.05)$. The dose-response models fitted to adults fed Ak and $\mathrm{Ak}+\mathrm{Sc}$ in the $\mathrm{F} 3$ generation did not adjust by an equality test $\left(\chi^{2}=17.82, P<0.05, \mathrm{df}=2\right)$ nor for parallelism $\left(\chi^{2}=15.80, P<0.05, \mathrm{df}=1\right)$. These variations represent the differences found on $\mathrm{LD}_{50 \mathrm{~s}}$ estimated for $H$. axyridis that fed on $\mathrm{Ak}\left(0.008 \mathrm{~g} l^{-1}\right)$ compared with those given $\mathrm{Ak}+\mathrm{Sc}\left(0.003 \mathrm{~g} l^{-1}\right.$ of lambdacyhalothrin) (Table 1). However, the models could be fitted to adults fed $\mathrm{Ak}$ and $\mathrm{Ag}$ in the $\mathrm{F} 8$ generation adjusted [(test for equality, $\chi^{2}=4.34, P>0.05, \mathrm{df}=2$, and parallelism, $\left.\chi^{2}=2.18, P>0.05, \mathrm{df}=1\right)$. For beetles fed $\mathrm{Ag}$

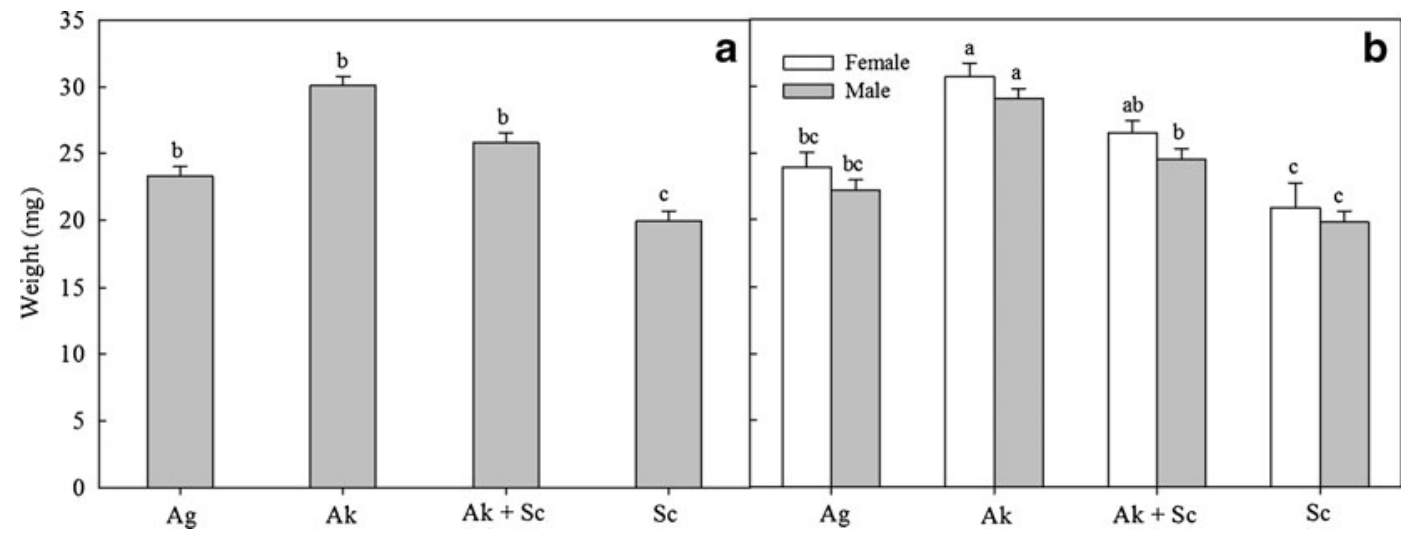

Fig. 2 Adult body weights (a) (mean \pm SE) and sex-specific body weights (b) (mean $\pm \mathrm{SE}$ ) of Harmonia axyridis reared on Aphis gossypii (Ag), eggs of Anagasta kuehniella (Ak), eggs of Sitotroga cerealella + Anagasta kuehniella $(\mathrm{Ak}+\mathrm{Sc})$ and eggs of Sitotroga cerealella (Sc), respectively (a) and (b). In each section, columns under a common letter do not differ statistically between diets at 0.05 significance levels (Tukey's test) 
Table 1 Adult reproductive characteristics of Harmonia axyridis and performance of adults treated with the insecticide lambda-cyhalothrin when reared on Aphis gossypii (Ag), Anagasta kuehniella (Ak), Sitotroga cerealella (Sc), and 50:50
Anagasta kuehniella + Sitotroga cerealella $(\mathrm{Ak}+\mathrm{Sc})$. Temp. $25 \pm 1^{\circ} \mathrm{C}$, and 12 -h photophase. Within columns, means $( \pm \mathrm{SE})$ followed by a common letter do not differ significantly (Tukey's test: $P>0.05$ )

\begin{tabular}{lllllll}
\hline Diet & $\begin{array}{l}\text { Age of first } \\
\text { oviposition (days) }\end{array}$ & $\begin{array}{l}\text { Mean number of eggs } \\
\text { per female }\end{array}$ & Egg hatching (\%) & $\begin{array}{l}\text { Reproductive } \\
\text { period (days) }\end{array}$ & $\mathrm{LD}_{50}\left(\mathrm{CI}_{95 \%}\right)^{\mathrm{y}}$ & $\mathrm{LD}_{50}\left(\mathrm{CI}_{95 \%}\right)^{\mathrm{x}}$ \\
\hline $\mathrm{Ag}$ & $7.3 \pm 0.31 \mathrm{c}$ & $302.1 \pm 27.35 \mathrm{ab}$ & $57.9 \pm 4.99 \mathrm{a}$ & $12.3 \pm 0.47 \mathrm{~b}$ & - & $0.024(0.017-0.031)$ \\
$\mathrm{Ak}$ & $21.1 \pm 1.47 \mathrm{a}$ & $379.6 \pm 23.91 \mathrm{a}$ & $70.5 \pm 5.76 \mathrm{a}$ & $21.9 \pm 2.21 \mathrm{a}$ & $0.008(0.005-0.011)$ & $0.022(0.011-0.033)$ \\
$\mathrm{Sc}$ & $17.3 \pm 1.13 \mathrm{ab}$ & $51.6 \pm 15.64 \mathrm{c}$ & - & - & - & - \\
$\mathrm{Ak}+\mathrm{Sc}$ & $15.3 \pm 1.06 \mathrm{~b}$ & $262.9 \pm 27.53 \mathrm{~b}$ & $64.4 \pm 5.76 \mathrm{a}$ & $22.5 \pm 2.42 \mathrm{a}$ & $0.003(0.001-0.009)$ & - \\
\hline
\end{tabular}

${ }^{\mathrm{z}}$ Mean number of days required to produce 12 egg batches

${ }^{\mathrm{y}} \mathrm{LD}_{50}$ calculated at $\mathrm{F} 3$ generation of $H$. axyridis in $\mathrm{g}$ a.i. of lambda-cyhalothrin $/ l\left(95 \%\right.$ confidence intervals for $\left.\mathrm{LD}_{50}\right)$

${ }^{\mathrm{x}} \mathrm{LD}_{50}$ calculated at $\mathrm{F} 8$ generation of $H$. axyridis in $\mathrm{g}$ a.i. of lambda-cyhalothrin $/ l\left(95 \%\right.$ confidence intervals for $\left.\mathrm{LD}_{50}\right)$

and $\mathrm{Ak}$, both the $\mathrm{LD}_{50 \mathrm{~s}}$ and the results showed similarity for estimated $\mathrm{LD}_{50 \mathrm{~s}}$ as 0.024 and $0.022 \mathrm{~g}$ a.i. $l^{-1}$ of lambda-cyhalothrin (Table 1).

\section{Discussion}

The multicolored Asian lady beetle, H. axyridis, exhibited low performance when its larvae fed on $S$. cerealella eggs, despite the fact that this species is considered to be polyphagous and highly competitive (Koch et al. 2006; Lucas et al. 2007) and that this diet is widely used to rear predators and parasitoids. Olszac (1986) mentioned that the first instar of Propylea quatuordecimpunctata L. was not able to break the

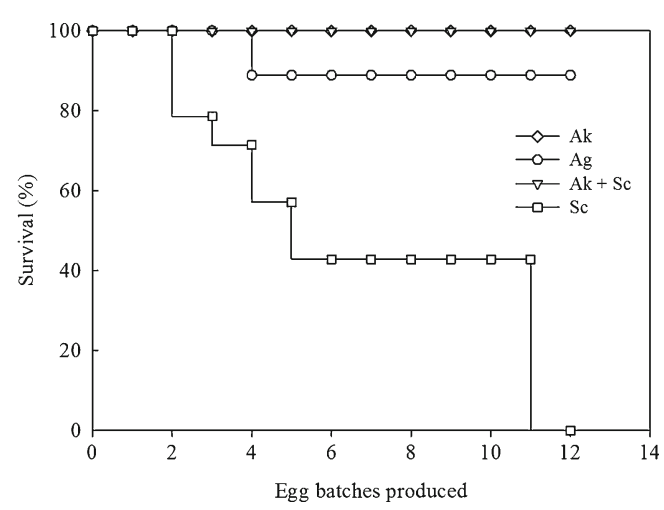

Fig. 3 Survival of Harmonia axyridis females during the reproductive period required to produce 12 egg batches, as a function of being reared on Aphis gossypii (Ag), eggs of Anagasta kuehniella (Ak), eggs of Sitotroga cerealella (Sc), or eggs of Anagasta kuehniella + Sitotroga cerealella $(\mathrm{Ak}+\mathrm{Sc})$. Survival curves for adult females differ in a statistically significant manner among diets through the Long-Rank test $\left(\chi^{2}=15.73, \mathrm{df}=3, P=0.0013\right.$ ) chorion of $S$. cerealella eggs. However, adults of this coccinelid succeeded when they were fed using $S$. cerealella eggs. In our study, the highest mortality of larvae was observed in the first instar of $H$. axyridis. If these larvae failed to break the chorion, the high mortality could be expected because they would not get enough nutrients to develop and complete the instar. Thus, the partial larval survival with few reaching adult stages reinforces the fact that older larvae were able to feed on $S$. cerealella eggs. This is surprising, considering that both Abdel-Salam \& AbdelBaky (2001) and Dong et al. (2001) have reported eggs of $S$. cerealella to be a suitable diet for $H$. axyridis. According to the latter authors, $H$. axyridis exhibited $84 \%$ and $80 \%$ larval survival and averaged 715.3 and 606.6 eggs per female when fed fresh and frozen $S$. cerealella eggs, respectively. The lower performance response of our $H$. axyridis population to $\mathrm{Sc}$ eggs is confirmed by the almost $50 \%$ proportional improvement on the biological performance when the Sc eggs were combined with a better diet (Ak eggs) at a $50 \%$ ratio. However, it is important to mention that the diet used to rear $S$. cerealella by Abdel-Salam \& Abdel-Baky (2001) and Dong et al. (2001) could be different from ours, and this fact could change the qualitative and quantitative contents of the $S$. cerealella eggs.

On the other hand, when we fed Ak eggs or $A$. gossypii to $H$. axyridis, our results for its development and reproduction fit within the variation reported in other studies, and when using lepidopteran eggs, our results were either similar or superior to published reports (Berkvens et al. 2008; Reznik 2010; Schanderl et al. 1988; Specty et al. 2003). 
Dietary effects upon immature stages of $H$. axyridis, especially on development time and larval survival, have been highlighted by Pervez \& Omkar (2006). Based on our results, H. axyridis larvae that fed on A. gossypii or A. kuehniella eggs exhibited shorter development times and greater survival, and produced larger adults compared with larvae reared on $\mathrm{Sc}$ eggs or the combination of $\mathrm{Ak}+\mathrm{Sc}$ eggs. According to Dixon (2000), the time that coccinellid beetles require to develop usually exhibits a negative correlation with adult body weight, i.e., smaller adults result from faster developing larvae. Our results using A. gossypii as prey corroborated this correlation (Fig. 1a). The negative correlation might be associated with diet quality, however, because suitable diets can produce large adults even when larvae are developing more rapidly (Michaud 2000; Pervez \& Omkar 2006), as we found in this study when comparing Ak and $\mathrm{Ag}$ diets (Figs. 1 and 2).

Our findings reinforce the use of Ak eggs as a quality diet for $H$. axyridis. Michaud (2005) suggests that the suitability of a diet for coccinellids can be evaluated by considering, in increasing order of importance, the outcome on immature viability, development time, and weight of the adults. This is a sensible approach because the viability of the immature stages and the weight of adults are strongly associated with reproductive success in coccinellids, as represented by the number of pairs formed and offspring produced.

Females of $H$. axyridis that had fed on A. gossypii initiated oviposition earlier than did adults from other studied diets (Table 1). Michaud (2005) considers the age of first oviposition to be a trait of coccinellid life history that has little meaning for group performance when evaluating diets, because this parameter is highly variable among coccinellids in general and also among individuals within a tested group. However, anticipation of oviposition coupled with concentration of offspring production, equivalent to production of at least 12 egg batches, demonstrates a better performance of $H$. axyridis fed $A$. gossypii despite the polyphagous feeding habit of this species (Hodek \& Honěk 1996). Furthermore, peaks of offspring production on time might be of adaptive value for $H$. axyridis females fed A. gossypii, considering that colonies of aphids are usually abundant for only a short period of time (Dixon 2000).

The variable results for development, adult body weight, and reproduction of $H$. axyridis reared on $\mathrm{Sc}$ eggs were similar to the outcome obtained by Michaud (2000) when feeding H. axyridis larvae with the aphid Aphis spiraecola Patch. This similarity suggests that these types of diet are suitable for $H$. axyridis development, but are diets of low quality to the species.

Although Abdel-Salam \& Abdel-Baky (2001) reared $H$. axyridis with eggs of $S$. cerealella and stated that the diet was adequate for development and reproduction of the species, in our study, $H$. axyridis females fed Sc eggs produced significantly fewer eggs compared with the other tested diets and the eggs did not hatch (Table 1). We repeated our study a second time to avoid any potential unknown effect of the diet or individuals, and again found low reproduction (data not shown here). In fact, when we reared larvae on Sc to obtain beetles for a bioassay to ascertain dietary effects on performance of adults treated with lambdacyhalothrin, a group of 300 neonate larvae yielded only 30 adults, an insufficient number for the toxicity test (minimum, 120 testable individuals). However, upon adding $50 \%$ of a more suitable prey (Ak eggs) into the diet mixture, the development and adult characteristics were improved almost at the same ratio (Figs. 1 and 2; Table 1). Based on our results and a published diet ranking for coccinellids (Hodek \& Honěk 1996), eggs of $S$. cerealella might better be considered as an alternative food for maintenance of $H$. axyridis, used in association with another prey that allows better reproduction and development. Both our research and published reports (Reznik 2010; Schanderl et al. 1988) indicate that eggs of A. kuehniella are potentially a better prey for $H$. axyridis larvae compared with $S$. cerealella eggs. In fact, Schanderl et al. (1988) suggested the use of A. kuehniella eggs for mass production of this species and Semiadalia undecinotata Scheneideer for biological control programs.

Despite the variability in development and reproduction that occurred as a function of diet, responses of $H$. axyridis adults to the insecticide lambdacyhalothrin were quite similar. The only difference was related to the small slope of the fitted model for adults from larvae fed $\mathrm{Sc}+\mathrm{Ak}$ eggs. This outcome might have been an effect of diet quality, because results for the $\mathrm{Sc}+\mathrm{Ak}$ diet were intermediate to those for feeding with Ak alone. However, the response of $H$. axyridis based on the $\mathrm{LD}_{50 \text { s }}$ calculated for adults from each diet did not correlate with the variation observed on development and reproduction among 
diets. The only observed differences for $\mathrm{LD}_{50 \text { s }}$ occurred between generations F3 and F8, and that is considered to be a typical natural variation of populations (Robertson et al. 1995).

Diverse effects could be produced in larvae and adults of $H$. axyridis after lambda-cyhalothrin exposure. Reduced predation efficacy and mobility of larva, and high acute toxicity could be mentioned as examples of these effects (Provost et al. 2003, 2005; Rodrigues 2012; Ruberson et al. 2007; Torres \& Ruberson 2005). The high susceptibility of $H$. axyridis to lambda-cyhalothrin found here is comparable to other pyrethroid insecticides, such as fenpropathrin, esfenvalerate, bifenthrin at field rates under laboratory conditions (Cho et al. 1997; Galvan et al. 2005, 2006; Michaud 2002; Michaud \& Grant 2003). Overall, conventional insecticides (carbamate, organophoshate and pyrethroid) are considered lethal for younger stages and adults of $H$. axyridis, but some new products could have reduced toxicity depending on the life stage, for example, spinosad and indoxacarb (Galvan et al. 2005; Youn et al. 2003). In addition, the high acute toxicity to $H$. axyridis is compared to the susceptibility of other lady beetles such as Hippodamia convergens Guerin-Meneville, Coccinela septempunctata (L.) (Ruberson et al. 2007; Tillman \& Mulrooney 2000; Torres \& Ruberson 2005), and Eriopis connexa (Germar) (Rodrigues 2012).

Despite the well-documented polyphagous and voracious feeding behavior exhibited by $H$. axyridis (Koch 2003; Koch et al. 2006; Lucas et al. 2007), our results showed that this species' performance is variable as a function of its diet during development, and that dietary effects on development and reproduction did not correlate with adult response to a strong stressor agent such as the insecticide lambdacyhalothrin. Therefore, our results did not support either of the proposed hypotheses for this study, i.e., that (i) the generalist feeding behavior of $H$. axyridis furnishes this species with the ability to have similar development and reproduction on different types of diets; or (ii) adult beetle responses to a stressor agent in the form of lambda-cyhalothrin, an insecticide widely used in the agroecosystems inhabited by the species, could be mediated by larval diet. However, it is important to note that $H$. axyridis in Brazil comes from a non-intentional introduction and the spread of its population from that introductory point to other regions has been comparatively recent. Thus, the $H$. axyridis in our study represent a relatively naive population with few generations of exposure to this insecticide.

Acknowledgments Partial funding for this project was provided by 'Conselho Nacional de Desenvolvimento Científico e Tecnológico - CNPq (Edital Universal Proc 473211/2009-2' and graduate grants to A.R.S.R. and A.F.S., and research grants to J.B.T. and J.E.M.O). Also, by 'Fundação de Amparo à Ciência e Tecnologia do Estado de Pernambuco - FACEPE', and 'Coordenação de Aperfeiçoamento de Pessoal de Nível Superior’ — CAPES Foundation (PDEE-7095-10-4).

\section{References}

Abdel-Salam, A. H., \& Abdel-Baky, N. F. (2001). Life table and biological studies of Harmonia axyridis Pallas (Col., Coccinellidae) reared on the grain moth eggs of Sitotroga cerealella Olivier (Lepidoptera: Gelechiidae). Journal of Applied Entomology, 125, 455-462.

Almeida, L. M., \& Silva, V. B. (2002). First record of Harmonia axyridis (Pallas) (Coleoptera, Coccinellidae): a lady beetle native to the Palaearctic region. Revista Brasileira de Zoologia, 19, 941-944.

Berkvens, N., Bonte, J., Berkvens, D., Tirry, L., \& De Clercq, P. (2008). Influence of diet and photoperiod on development and reproduction of European populations of Harmonia axyridis (Pallas) (Coleoptera: Coccinellidae). BioControl, 53, 211-221.

Brown, P. M. J., Adriaens, T., Bathon, H., Cuppen, J., Goldarazena, A., Hägg, T., et al. (2008). Harmonia axyridis in Europe: spread and distribution of a non-native coccinellid. BioControl, 53, 5-21.

Cho, J., Hong, K. J., Yoo, J. K., Bang, J. R., \& Lee, J. O. (1997). Comparative toxicity of selected insecticides to Aphis citricola, Myzus malisuctus (Homoptera: Aphididae), and the predator Harmonia axyridis (Coleoptera: Coccinellidae). Journal of Economic Entomology, 90, 11-14.

Dixon, A. F. G. (2000). Insect predator-prey dynamics: Ladybird beetles and biological control. Cambridge, UK: Cambridge University Press.

Dixon, A. F. G., \& Agarwala, B. K. (2002). Triangular fecundity function and ageing in ladybird beetles. Ecological Entomology, 27, 433-440.

Dong, H., Ellington, J. J., \& Remmenga, M. D. (2001). An artificial diet for the lady beetle Harmonia axyridis Pallas (Coleoptera: Coccinellidae). Southwestern Entomologist, 26, 205-213.

Evans, E. W. (2003). Searching and reproductive behaviour of female aphidophagous ladybirds (Coleoptera: Coccinellidae): a review. European Journal of Entomology, 100, 1-10.

Eveleens, K. G., Van den Bosch, R., \& Ehler, L. E. (1973). Secondary outbreak induction of beet armyworm by experimental insecticide applications in cotton in California. Environmental Entomology, 2, 497-503.

Finney, D. J. (1971). Probit analysis. London, UK: Cambridge University Press.

Galvan, T. L., Burkness, E. C., \& Hutchison, W. D. (2006). Efficacy of selected insecticides for management of the 
multicolored Asian lady beetle on wine grapes near harvest. Plant Health Progress. doi:10.1094/PHP2006-1003-01-RS.

Galvan, T. L., Koch, R. L., \& Hutchison, W. D. (2005). Toxicity of commonly used insecticides in sweet corn and soybean to the multicolored Asian lady beetle (Coleoptera: Coccinellidae). Journal of Economic Entomology, 98, 780-789.

Gautam, R. D. (1990). Mass-multiplication technique of coccinellid predator, lady bird beetle (Brumoides suturalis). Indian Journal of Agricultural Sciences, 60, 747-750.

Hodek, I., \& Honěk, A. (1996). Ecology of Coccinellidae. Dordrecht, the Netherlands: Kluwer Academic.

Honěk, A. (1991). Environment stress, plant quality and abundance of cereal aphids (Hom., Aphididae) on winter wheat. Journal of Applied Entomology. doi:10.1111/j.14390418.1991.tb01030.x.

Kamo, T., Tokuoka, Y., \& Miyazaki, M. (2010). Influence of aphid-host plant pairs on the survivorship and development of the multicolored Asian ladybird beetle: implications for the management of vegetation in rural landscapes. Ecological Research, 25, 1141-1149.

Koch, R. L. (2003). The multicolored Asian lady beetle, Harmonia axyridis: a review of its biology, uses in biological control, and non-target impacts. Journal of Insect Science, 3, 32.

Koch, R. L., Venette, R. C., \& Hutchison, W. D. (2006). Invasions by Harmonia axyridis (Pallas) (Coleoptera: Coccinellidae) in the Western Hemisphere: implications for South America. Neotropical Entomology, 35, 421-434.

Kogan, M. (1998). Integrated pest management: historical perspectives and contemporary developments. Annual Review of Entomology, 43, 243-270.

L. O. Software (1987). POLO-PC: A user's guide to Probit Logit analysis. Berkeley, CA, USA: Leora Software.

Lucas, E., Vincent, C. H., Labrie, G. E., Chouinard, G. E., Fournier, F. R., Pelletier, F. R., et al. (2007). The multicolored Asian ladybeetle Harmonia axyridis (Coleoptera: Coccinellidae) in Quebec agroecosystems ten years after its arrival. European Journal of Entomology, 104, 737-743.

McCornack, B. P., Koch, R. L., \& Ragsdale, D. W. (2007). A simple method for in-field sex determination of the multicolored Asian lady beetle Harmonia axyridis. Journal of Insect Science, 7, 1-12.

Michaud, J. P. (2000). Development and reproduction of ladybeetles (Coleoptera: Coccinellidae) on the citrus aphids Aphis spiraecola Patch and Toxoptera citricida (Kirkaldy) (Homoptera: Aphididae). Biological Control, 18, 287-297.

Michaud, J. P. (2002). Relative toxicity of six insecticides to Cycloneda sanguinea and Harmonia axyridis (Coleoptera: Coccinellidae). Journal of Entomological Science, 37, 82-93.

Michaud, J. P. (2005). On the assessment of prey suitability in aphidophagous Coccinellidae. European Journal of Entomology, 102, 385-390.

Michaud, J. P., \& Grant, A. K. (2003). IPM-compatibility of foliar insecticides for citrus: indices derived from toxicity to beneficial insects from four orders. Journal of Insect Science, 3, 18.

Michaud, J. P., \& Grant, A. K. (2005). Suitability of pollen sources for the development and reproduction of Coleomegilla maculata (Coleoptera: Coccinellidae) under simulated drought conditions. Biological Control, 32, 363-370.

Musser, F. R., Nyrop, J. P., \& Shelton, A. M. (2004). Survey of predators and sampling method comparison in sweet corn. Journal of Economic Entomology, 97, 136-144.

Naranjo, S. E. (2001). Conservation and evaluation of natural enemies in IPM systems for Bemisia tabaci. Crop Protection, 20, 835-852.

Olszac, R. W. (1986). Suitability of three aphid species as prey for Propylea quatuordecimpunctata. In I. Hodek (Ed.), Ecology of Aphidophaga (pp. 51-56). Prague, Czechoslovakia: Academia.

Pervez, A., \& Omkar, G. M. (2006). Ecology and biological control application of multicolored Asian ladybird, Harmonia axyridis: a review. Biocontrol Science and Technology, 16, 111-128.

Provost, C., Coderre, D., Lucas, É., \& Bostanian, N. J. (2003). Impact of lambda-cyhalothrin on intraguild predation among three mite predators. Environmental Entomology, 32, 256-263.

Provost, C., Coderre, D., Lucas, É., Chouinard, G., \& Bostanian, N. J. (2005). Impact of intraguild predation and lambdacyhalothrin on predation efficacy of three acarophagous predators. Pest Management Science, 61, 532-538.

Reznik, S. Y. (2010). On the effects of diet and photoperiod on Harmonia axyridis (Pallas) (Coleoptera, Coccinellidae) larval development. Entomological Review, 90, 411-414.

Robertson, J. L., Preisler, H. K., Ng, S. S., Hickle, L. A., \& Gelernter, W. D. (1995). Natural variation: a complicating factor in bioassays with chemical and microbial pesticides. Journal of Economic Entomology, 88, 1-10.

Rodrigues, A. R. S. (2012). Caracterização da resistência de joaninhas predadoras ao lambda-cialotrina. (Characterization of resistance to lambda-cyhalothrin in predatory ladybeetles). http://www.ppgea.ufrpe.br/novosite/images/Teses/ agnarodrigues.pdf. Accessed 12 November 2012.

Ruberson, J. R., Nemoto, H., \& Hirose, Y. (1998). Pesticides and conservation of natural enemies in pest management. In P. Barbosa (Ed.), Conservation biological control (pp. 207-220). New York, NY: Academic.

Ruberson, J. R., Roberts, P., \& Michaud, J. P. (2007). Pyrethroid resistance in Georgia populations of the predator Hippodamia convergens (Coleoptera: Coccinellidae). Proceedings of Beltwide Cotton Conference, 1, 361-365.

Ruberson, J. R., \& Tillman, P. G. (1999). Effect of selected insecticides on natural enemies in cotton: a laboratory study. Proceedings of Beltwide Cotton Conference, 2, 1210-1213.

Rutledge, C. E., O’Neil, R. J., Fox, T. B., \& Landis, D. A. (2004). Soybean aphid predators and their use in integrated pest management. Annals of the Entomological Society of America, 97, 240-248.

Saini, E. D. (2004). Presencia de Harmonia axyridis (Pallas) (Coleoptera: Coccinellidae) en la provincia de Buenos Aires. Aspectos biológicos y morfológicos. Revista de Investigaciones Agropecuárias, 33, 151-160.

SAS Institute. (2001). SAS/STAT User's guide, version 8.02, TS level 2MO. Cary, NC, USA: SAS Institute Inc.

Schanderl, H., Ferran, A., \& Gracia, V. (1988). Rearing two coccinellids, Harmonia axyridis and Semiadalia undecinotata on eggs of Anagasta kuehniella killed by exposure to UV radiation. Entomologia Experimentalis et Applicata, $49,235-244$. 
Specty, O., Febvay, G., Grenier, S., Delobel, B., Piotte, C., Pageaux, J.-F., et al. (2003). Nutritional plasticity of the predatory ladybeetle Harmonia axyridis (Coleoptera: Coccinellidae): comparison between natural and substitution prey. Archives of Insect Biochemistry and Physiology, 52, 81-91.

Tillman, P. G., \& Mulrooney, J. E. (2000). Effect of selected insecticides on the natural enemies Coleomegilla maculata and Hippodamia convergens (Coleoptera: Coccinellidae), Geocoris punctipes (Hemiptera: Lygaidae), and Bracon melitor, Cardiochiles nigriceps, and Cotesia marginiventris (Hymenoptera: Braconidae) in cotton. Journal of Economic Entomology, 93, 1638-1643.

Torres, J. B., Barros, E. M., Coelho, R. R., \& Pimentel, R. M. M. (2010). Zoophytophagous pentatomids feeding on plants and implications for biological control. Arthropod Plant Interaction, 4, 219-227.
Torres, J. B., Bastos, C. S., \& Pratissoli, D. (2009). Controle biológico de pragas com uso de insetos predadores. Informe Agropecuário, 30, 17-32.

Torres, J. B., Freitas, F. S., \& Pratissoli, D. (1995). Avaliação de diferentes porcentagens da mistura de farinha de milho com farinha de trigo integral e levedura-de-cerveja na criação de Anagasta kuehniella (Zeller, 1879). Ciência e Prática, 19, 365-368.

Torres, J. B., \& Ruberson, J. R. (2005). Canopy- and grounddwelling predatory arthropods in commercial $B t$ and nonBt cotton fields: patterns and mechanisms. Environmental Entomology, 34, 1242-1256.

Youn, Y. N., Seo, M. J., Shin, J. G., Jang, C., \& Yu, Y. M. (2003). Toxicity of greenhouse pesticides to multicolored Asian lady beetles, Harmonia axyridis (Coleoptera: Coccinellidae). Biological Control, 28, 164-170. 